\title{
The Reciprocity Thesis in Kant and Hegel
}

\section{Alan Patten}

\section{The Reciprocity Thesis}

Following Henry Allison's terminology in his book Kant's Theory of Freedom I shall take the reciprocity thesis to be the thesis that morality and freedom are reciprocal concepts. To be free, the reciprocity thesis claims, is to be subject to the demands of morality; to be subject to the demands of morality is to be free. ${ }^{2}$

Despite quite different understandings of the domains of ethics and morality, Kant and Hegel both affirm versions of the reciprocity thesis. ${ }^{2}$ Kant's best known statement of the thesis can be found at the beginning of Chapter III of the Groundwork of the Metaphysics of Morals: "a free will and a will under moral laws", he asserts, "are one and the same. Consequently if freedom of the will is presupposed, morality, together with its principle, follows by mere analysis of the concept of freedom". 3 This assumption of reciprocity is an explicit premise in the subsequent argument that, since a rational agent must take himself to be free, he must consider himself subject to the moral law. And it reappears again in the Critique of Practical Reason's reversal of this argument, which claims that, since a rational agent has a sense of himself as subject to the moral law (the so-called 'fact of reason'), he therefore has a consciousness of his freedom. ${ }^{4}$ Finally, it is worth noting that something like the reciprocity thesis underlies much of the argument of Chapters I and II of the Groundwork as well as the opening arguments of the second Critique: for in these texts Kant frequently moves directly from the proposition that the moral will must be determined independently of all of its desires and inclinations (it is free) to the conclusion that it must be subject to the moral law.

For Hegel, the requirements of duty and morality are not expressed by a moral law, or Categorical Imperative, but are to be found in the customary ends and obligations of the major institutions of the modern community - principally the family, civil society, and the state. This does not stop Hegel, however, from joining Kant in explicitly affirming the reciprocity thesis. Commenting on Kant, for instance, Hegel asserts that 'In doing my duty, I am with myself and free. The merit and exalted viewpoint of Kant's moral philosophy are that it has emphasized this significance of duty". Hegel also claims that "an immanent and consistent theory of duties can be nothing other than the development of those relations which are necessitated by the Idea of freedom..." and that "in duty, the individual liberates himself so as to attain substantial freedom".7 This reciprocity thesis is one of the key premises in Hegel's argument that the state, and the modern community more generally, represent the full actualization of freedom.

It is clear that for Kant, at least, the case for the reciprocity thesis is grounded in a particular view of freedom as rational self-determination. For Kant, an agent is fully free or autonomous if and only if there can be a determining ground of his action which does not have its basis in nature - in the agent's empirically given desires, inclinations, and so on - but only 
in his own thought and reason alone. ${ }^{8}$ It is controversial, however, how far Hegel shares this Kantian understanding of freedom. It is sometimes argued that Hegel saw himself as taking a much more accommodating, and less dualistic, view of the relationship between an agent's freedom and his given desires and inclinations. Hegel emphasizes, for instance, that the presence of subjective interests and desires are an indispensable condition of there being any action at all. ${ }^{9}$ And he clearly disapproves of what he takes to be the Kantian position that morality involves a struggle between reason and the inclinations. ${ }^{10}$ In my view, however, there remains an important Kantian core to Hegel's conception of freedom. A careful reading of Paragraphs 10 to 21 of the Philosophy of Right, and attention to numerous other passages in which Hegel does acknowledge a conflict between freedom and nature ${ }^{11}$ suggest that, despite the objections that Hegel does level against Kant, he does not reject the Kantian view of freedom altogether. Even if Hegel denies (sensibly enough) that a free action can be motivated by reason alone, and even if he holds that certain feelings and emotions have ethical significance, he does none the less maintain that the content of free action must be rational, that such an action must be performed from a rational or appropriate motive, and that it must be performed with an awareness of its rationality - where in each case the criterion of rationality that is appealed to is an essentially Kantian one which excludes the agent's given desires and inclinations and looks to reason instead. ${ }^{12}$

In any event, for the purposes of this paper, I will assume that Hegel shares a broadly Kantian conception of freedom as rational self-determination in order to focus on the second step in the case for the reciprocity thesis in Kant and Hegel respectively: the defense of the claim that an agent who is fully guided by his own thought and reason is necessarily an agent who is subject to ethical requirements. I try to develop quite close readings of the relevant texts to argue for two claims. The first is that Kant's specific argument for the reciprocity thesis, even as defended by recent commentators such as Henry Allison and Christine Korsgaard, cannot be judged a success. And the second is that Hegel seems to offer at least some of the resources towards a more promising defense of that thesis.

\section{The Vacuity Objection}

A major objection to the view that freedom consists in rational self-determination is that freedom, on this view, becomes essentially vacuous: the conditions that an agent must satisfy in order to qualify as rationally self-determining are such that there never has been, and never could be, a free agent.

This objection, which I shall term the vacuity objection, can take a number of different forms. The most famous of these is directed at Kantians in particular and is given its strongest and best-known statement by Hegel himself. ${ }^{13}$ Hegel argues that the Kantian procedure for determining what particular ends and duties give content to an agent's freedom - the categorical imperative test - is essentially indiscriminate. Kant's test requires that agents act only on maxims which they could at the same time will to be universal law. The core of 
Hegel's argument is the claim that every maxim is capable of passing this test and thus that every action counts as morally permissible and expressive of the agent's freedom. The Kantian account of freedom is vacuous in the sense that it cannot distinguish free from unfree actions.

Although there is a long tradition of endorsing Hegel's objection to Kant's categorical imperative test, most recent commentators agree that it is mistaken. ${ }^{14}$ There is a natural interpretation of Kant's test according to which it clearly can generate contradictions and rule some maxims out without at the same time rejecting every maxim. If Kant's test is seen as looking for contradictions between (1) willing the purpose contained in the maxim and (2) willing that the maxim be universalised, then it clearly does have particular content and is not, as Hegel maintains, an "empty formalism". ${ }^{15}$ Contrary to what Hegel claims, in Kant's famous deposit example, for instance, there would be a contradiction, because the agent would, in effect, be willing both that he increase his property (the purpose contained in the maxim) and that the means through which he intends to do this - the institution of deposit-leaving - not be present (the implication of universalising the maxim); he would be willing both the end and the abolition of the necessary means.

There is however a second, potentially more damaging, form that the vacuity objection can take, which I want to explore in this chapter. The problem, as Christine Korsgaard has pointed out, takes the form of a regress and relates, in Kant's case, to the derivation of the categorical imperative rather than to its content. ${ }^{16}$ We can imagine asking an agent why she acted as she did and her answering with an appeal to some desire or authority. We then ask her why she takes that desire or authority to be a reason-for-action and she responds by citing some further desire or authority. And so on. Eventually, the agent may simply put a stop to this chain of reason-giving by insisting that some desire or authority constitutes her bedrock reason-for-action. If she does this, however, then she would not be fully free in Kant and Hegel's sense because she would be simply accepting an external instruction that she could subject to her own thought and reason. On the other, if she does not put a stop to her deliberations in this way, then it seems that her chain of reasoning must extend ad infinitum. Either way, it seems that there never has been or could be a rationally self-determining agent. Charles Taylor summarises this argument effectively when he says:

The dilemma of radical freedom can be restated succinctly as follows: if freedom is to renounce all heteronomy, any determination of the will by particular desires, traditional principle or external authority, then freedom seems incompatible with any rational action whatsoever. For there do not seem to be any grounds of action left, which are not wholly vacuous, that is which would actually rule some actions in and others out, and which are not also heteronomous. ${ }^{17}$ 
Hegel himself implicitly draws attention to this form of the vacuity objection in an interesting passage from his 1824-25 lectures:

These are the two moments which belong to the will as such. The first is the negation of all that is particular, the second the negation of all indeterminacy; the first is the transition to indeterminacy, the second the transition to particularity; the first is the cutting loose from all determination, the second the positing of all determination. Every man will find these two determinations in his self-consciousness: this is freedom. Man appears now as a being full of contradictions; he is contradiction itself and only this way comes to consciousness. The power of spirit is to be able to endure this contradiction; no other natural being can exist with it. Spirit, however, is not merely the existence of this contradiction, but is just as much its resolution, and this is the concept of the will. ${ }^{18}$

Here Hegel acknowledges that the abstraction requirement - the requirement that the will be independent of all authority and of all of its contingently given desires and inclinations - is in conflict with the idea that the will has particular determinate content, thus generating a "contradiction" in human freedom. The more that abstraction and critical reflection are emphasised as conditions of freedom the more it seems that there never has been or never could be a free agent. ${ }^{19}$

It is precisely this objection that both Kant and Hegel must address in their arguments for the reciprocity thesis. They must show that an agent who is independent of all authority and of all his contingently given desires and inclinations - an agent who in some sense acts on pure reason -does nevertheless have at least one reason-for-action and that is to follow certain ethical standards. In the remainder of this paper I want to reconstruct the arguments for this claim put forward by Kant and Hegel respectively. I shall argue that, whereas Kant fails to defend the claim adequately, Hegel's own argument for it is in certain respects quite promising.

\section{Kant's Argument for the Reciprocity Thesis}

Kant's most explicit statements of the reciprocity thesis can be found in the opening paragraphs of Groundwork $I I I$ and in $\$ 5$ and $\$ 6$ of the Analytic in the Critique of Practical Reason. $^{20}$ Although the terminology is somewhat different in each version, and, as Henry Allison has pointed out, the assumption of transcendental freedom is more explicit in the second Critique than in the Groundwork, ${ }^{21}$ the basic argument in each text is more or less the same. While this argument might be set out in a number of different ways, I have sought to reduce it down to three essential steps, focusing on Kant's proposition that the free will is necessarily subject to the Categorical Imperative. 
(1) The first step is the assumption that a rational agent can and must have one or other of two sorts of reasons-for-action as the "determining ground" of his action. His determining ground must consist either in (i) some given desire or inclination of his that will be satisfied by the action, or in (ii) the "legislative form" of his "maxim" - that is, its capacity to be universalised, or to be willed at the same time as a universal law for all rational agents. Kant identifies the first sort of determining ground with the "material" or "matter" of the agent's maxim or practical law and the second with the "form" of that maxim or law.

(2) The second step appeals to the premise (taken for granted in this paper) that to the extent that the agent is free or autonomous, it is not sufficient for him to appeal to some given desire or inclination as his reason-for-action any more than it is for him to appeal to some external authority; his determining ground must be something different.

(3) And the third step simply draws out the logical implication of the first two. To put it in Kant's own words: "Therefore, the legislative form, in so far as it is contained in the maxim, is the only thing which can constitute a determining ground of the [free] will"22 In other words, a free will is a will that is subject to the demands of the Categorical Imperative.

Since the conclusion does seem to follow from the two premises, and I have assumed that something like (2) can be defended in terms of everyday ideas that we have about freedom, the weight of the argument must now fall onto (1). Is Kant justified in asserting that a rational agent must have as his "determining ground" one or other of the two sorts of reasons-for-action mentioned in (1)? I shall argue that he is not and that the argument therefore fails. In particular, I shall argue that there are two ways a Kantian might try to defend (1). On the first, (1) does not offer an exhaustive catalogue of the different kinds of reasons-for-action that an agent might appeal to in justifying his action. On the second, there is no defensible distinction between the two sorts of reasons mentioned in (1). Either way, the argument - which works by elimination - does not go through. ${ }^{23}$

The standard Kantian case for (1) is I think the following. ${ }^{24}$ There are reasons-foraction which appeal to one's desires and inclinations and there are those which do not. Since what distinguishes one rational agent from another is the desires and inclinations they each have, reasons-for-action which are not grounded in desires and inclinations must be reasons which apply to any rational agent as such and in this sense have the property of universality. There are thus two sorts of reasons: those which appeal to desires and inclinations; and those which have the property of universality. But this is all that (1) says: for it says that there are two sorts of reasons-for-action which might serve as the determining ground of a rational agent - those which appeal to the agent's given desires and inclinations and those which appeal to the universalizability of the agent's maxim. Therefore, (1) is correct.

The problem with this argument is that it runs together two importantly different senses of universality or universalizability. ${ }^{25}$ On one sense of the term, an agent's reason-foraction is universalizable, or has the property of universality, if and only if it is a reason for every rational agent as such. In a second sense, an agent's reason-for-action is universalizable, 
or has the property of universality, if and only if the agent could at the same time will that every relevantly situated rational agent act on that reason. These two senses of universality are clearly not equivalent. I am acting universally in the first sense when I can acknowledge (ie when it is the case) that other similarly situated agents have reason to perform the same action as I do. By contrast universality in the second sense requires not only that $\mathrm{I}$ be able to acknowledge that other agents have the same reason as $I$ do but also that $I$ be able to will that those others actually do what they have reason to do.

Allen Wood, who originated this line of objection, illustrates the distinction between the two senses of universality by imagining someone who acts on a principle of rational egoism. ${ }^{26}$ Such a person could conceivably acknowledge that every rational agent has reason to follow this principle and at the same time be thankful that other rational agents are too cowardly, or uptight, to do what they have reason to do. He could not will that others act from the principle of rational egoism (because this might well conflict with his own pursuit of advantage), but he could acknowledge that they would be acting reasonably if they did.

The Kantian argument I outlined for (1) starts by assuming universality in the first weaker sense. The plausibility of this rests on the thought that an agent who does not have as his determining ground some desire or inclination (something which is particular to him) must then have as his determining ground some reason-for-action that applies to any rational agent as such. But the conclusion of the argument was then expressed in terms of universality in the second sense - that the determining ground of an agent's action must either be desirebased or refer to the legislative form of the agent's maxim. Since the two senses of universality are not equivalent, a gap in the argument for (1) clearly remains. As it stands, there seems to be no reason to think that the catalogue of possible reasons given in (1) is an exhaustive one; as the example of the rational egoist is meant to suggest, there could be nondesire-based reasons other than the legislative form of one's maxim.

Henry Allison has attempted to defend Kant against this kind of objection by arguing that it ignores Kant's explicit assumption of transcendental freedom. When transcendental freedom is plugged into the gap, Allison maintains, it becomes clear that a principle of rational egoism, say, could not in fact serve as a determining ground of the will. The reason for this is that principles such as the principle of rational egoism covertly assume a "material" determining ground of the will. 'Such a policy is deemed reasonable in the first place", according to Allison, "only because of certain presupposed ends, which derive whatever justification they might possess from the agent's desires. Consequently, these desires and not the intrinsic reasonableness or lawfulness of the policy function as the 'determining ground of the will'."27

For both Kant and Hegel, an agent who justifies his action to himself merely by appealing to some given desire lacks full autonomy or freedom. Freedom requires that he stand back from his desire and reflect on whether it is a good thing that he act on it or not that he advance a reason or justification on its behalf. Moreover, it is not enough that he 
justify his desire simply by appealing to some other desire of his, because then the same question just arises again. Allison seems to be making the same point about the agent who attempts to justify acting on some desire by appealing to the principle of rational egoism: to be free, he is claiming, the agent would have to be able to advance some reason or justification for following that principle. And what else could this be but some desire or inclination - reopening the whole problem once again? The objection to the Kantian defense of (1) fails, then, because principles which are universal in the first sense but not in the second are not in fact universal at all: they covertly rest on some desire or inclination.

I think that Allison is right to insist that a Kantian should require that the principle of rational egoism itself be justified but wrong to think that he has thereby rescued (1) or Kant's attempt to show reciprocity between freedom and morality more generally. The problem with Allison's argument is this: if full autonomy requires that an agent rationally reflect on a principle such as the principle of rational egoism, then surely it also requires that the agent stand back and look for a justification for following the Categorical Imperative. Allison may be right to say that the principle of rational egoism could only be "deemed reasonable in the first place...because of certain presupposed ends", but would this not also be the case with the Categorical Imperative? Why would an agent recognize this principle as authoritative? Allison clearly thinks that the Categorical Imperative, unlike other possible principles, is intrinsically reasonable ${ }^{28}$ - the agent need ask for no further justification - but this begs the question. Why could the principle of rational egoism not be deemed intrinsically reasonable thus protecting it from the justification requirement as well?

In effect, I am arguing that on Allison's defense of (1) the distinction between the two sorts of reasons-for-action mentioned in (1) collapses altogether. There are no longer any reasons which can be deemed to have the property of universality, because all reasons turn out to rest covertly on desires and inclinations. And with the collapse of the distinction in (1) the overall argument clearly falls apart, since it proceeds by attempting to eliminate alternatives.

I suspect that at the back of Allison's mind may be two assumptions which are more explicitly made by Christine Korsgaard in her own discussion of Kant's reciprocity thesis. ${ }^{29}$ The first is that a "spontaneous" or transcendentally free agent - an agent who is free in Kant and Hegel's sense - has as a highest order reason or "incentive" the preservation and promotion of his spontaneity, his independence of all empirical conditions. The second is that someone who had this incentive would reject, upon deliberation, every principle of action except the principle of acting on only those maxims which could also be willed as universal law.

I will return to the first assumption in the next section when I look at Hegel's argument for the reciprocity thesis, so for now let me focus on the second assumption. It is important to note for a start that the second assumption is by no means obviously true, since it claims that an agent committed to the essentially self-regarding end of preserving and promoting his own spontaneity would necessarily reject the principle of rational egoism (which is also self- 
regarding) but endorse the other-regarding Categorical Imperative principle. So what argument does Korsgaard offer for this claim?

The only argument I can find is the rather disappointing one that "The moral law does not impose a constraint on the will; it merely says what it has to do in order to be an autonomous will at all. It has to choose a law". ${ }^{30}$ This argument is unpersuasive because it trades on an ambiguity in the idea that the will must "choose a law" which exactly mirrors the ambiguity in the term "universality" that I explored earlier. Korsgaard may be right to say that the will must "choose a law" if, by this, she means that it must always act on some reason or other, or even on some reason that applies to any rational agent as such. But as I argued earlier this is by no means equivalent to "choosing a law" in the sense of acting on a reason (or maxim) that one could at the same time will that others act on as well. It is not at all obvious why a will must "choose a law" in this second sense "in order to be an autonomous will at all".

Indeed this is precisely what needs to be shown by Kant and his defenders. Thus, on Korsgaard's reconstruction, the gap in Kant's argument identified earlier reappears. We still need to know why a free agent would necessarily act not just on a maxim that any rational agent as such would follow, but also on a maxim that he could at the same time will that all other rational agents follow.

I conclude that Kant's argument for the reciprocity thesis cannot be judged a success. The argument, as I set it out at the beginning of this section, is a valid one, but its key premise, premise (1), is never adequately justified. Premise (1) either does not offer an exhaustive catalogue of the different sorts of reasons-for-action that an agent might have or the distinction it proposes seems to collapse. Whichever is the case, Kant's argument that morality and freedom are reciprocal concepts is, in the end, dogmatic and indefensible.

\section{Hegel's Argument for the Reciprocity Thesis}

I turn now to Hegel's case for the reciprocity thesis. As I understand the argument, three points in particular are important. The first is Hegel's attempt to identify an end to which even an agent who is radically independent of not only all external authority, but also his own desires and inclinations, is still committed. The second step is to set out a strategy for deriving more specific ends and actions from this end. And the third is to indicate how this strategy points towards a subjection to ethical requirements and thus completes the argument for the reciprocity thesis. This section will look at each of these steps in order.

1 The first problem for Hegel is to identify some foundational principle or reason-foraction for a free agent: in order to bring an end to the regress we saw earlier, it must be a reason which the agent can appeal to in his practical deliberations, but which itself need not be deliberated about, but is exempt from the justification requirement. Kant, we saw, proposes the Categorical Imperative as such a foundational principle, but this proposal, I argued, is dogmatic and indefensible. 
Hegel, on the other hand, puts forward what I think must be the only possible reason that can fit the bill. He maintains that even when the will abstracts from all its contingently given desires and inclinations, and attempts to justify its action in terms of its own thought and reason alone, it remains committed to one important end, that of promoting and sustaining its own independence and freedom. Although, as I suggested earlier, this idea is implicitly attributed to Kant by Korsgaard, it is much more explicitly assumed by Hegel. ${ }^{31}$ For example, in the published text of the Philosophy of Right Hegel asserts that "when the will has universality, or itself as infinite form, as its content, object, and end, it is free not only in itself but also for itself - it is the Idea in its truth". In his 1817-18 lectures, he claims that "the will...is only free insofar as it makes itself its object and content, and thus wills itself, that is, insofar as it wills to be free". And in his 1822-23 lectures, he says that "the will in its truth is such that what it wills, ie its content, is identical with the will itself, so that freedom is willed by freedom". 32

So why should this principle - the principle of maintaining one's own freedom and independence - but not, say, Kant's Categorical Imperative be exempt from the justification requirement? Why does an appeal to this principle bring a halt to the regress? One of the interesting features of Hegel's theory of freedom is that it does contain, at least implicitly, resources to answer this question.

A central claim made by Hegel is that no one could be a free agent unless he takes himself to be free. ${ }^{33}$ The reason why the animal, the child, and even the slave is unfree, in Hegel's view, is that each lacks this special self-understanding. By this Hegel seems to mean not just that each lacks an awareness of being free, but also that each fails to attach sufficient value to being in this condition, each does not see his condition as an "improper one"34

To come to the point where one is independent of one's given desires and inclinations, Hegel is arguing, requires a certain set of mental attitudes and capacities. It demands, for instance, a capacity and willingness to distance oneself from one's immediate desires and inclinations and to subject them to critical examination. It depends on the imagination to conceive of oneself living a different kind of life than one is in: an awareness of oneself as having options and alternatives. And it requires the self-discipline to tear oneself away from one's desires and inclinations in order to pursue one's true or authentic goals. Unless the agent has this set of attitudes, goals and capacities, he could never engage in the kind of radical reflection and abstraction that sets up the regress problem in the first place. He would never ask the difficult questions about who he is, and what his true purposes are, that seem to give rise to the vacuity problem.

One implication of this is that there is an important sense in which the end or ideal of establishing and maintaining one's freedom is non-revisable: an agent could not, if Hegel's argument is correct, be a free agent and not be committed to this end. It is not an optional or contingent end from the point of view of a free agent, but one which partly constitutes his standpoint as a free agent. In this sense, the practical deliberations of a free agent have gone 
as far back as they can when they reach this end: a refusal to subject this end to critical examination could not be said to diminish such an agent's freedom, since a commitment to this end is the very basis of the desirability of subjecting one's ends to critical examination in the first place. To this extent an appeal to the principle of preserving and promoting one's freedom and independence puts a halt to the regress troubling the conception of freedom as rational self-determination.

Freedom requires detachment or abstraction from one's given desires, aims, goals, etc. It demands that one stand back and critically reflect on one's ends. Someone who is not critical in this way, someone who drifts through life unreflectively, is no freer than the agent who subjects himself to authority: both are content to allow something or somebody else to determine for them what they could think through for themselves. But, the activity of standing back and reflecting on one's given desires and goals presupposes a commitment to at least one end or goal - namely, the end of being free and independent. The regress problem would never arise for someone who is not committed to this end. But, if this is the case, then an appeal to this end - the end of establishing and preserving one's freedom - should bring a halt to the regress: for someone who appeals to this end could, without diminishing his freedom, neglect to subject $i t$ to critical examination on the grounds that the act of critically examining one's ends presupposes this end. ${ }^{35}$

The appeal to pure reason, which is so central to the conception of freedom as rational self-determination, is not, then, for Hegel, an appeal to some peculiar "houmenal" realm of reasons which is wholly different from an agent's set of desires and inclinations. That would hardly be coherent. ${ }^{36}$ Rather it is best understood as an appeal to an ordinary desire - the desire for freedom ("Der Trieb der Freiheit, das Bediurfniß der Freiheit"37) - which occupies a peculiar place in the structure of a free agent's practical reasoning: unlike his other desires, an agent can, without loss of freedom, act unreflectively on this desire since this desire is the very basis of the desirability of reflecting on his desires in the first place.

2. The second step in the argument, then, is to identify a strategy for connecting the general commitment to the end of establishing and maintaining one's freedom with more specific purposes and actions. In this context, we saw that Korsgaard moves directly from this general commitment to an endorsement of the Categorical Imperative, a move which I argued is fallacious. It is important to ask, then, what alternative strategy Hegel can propose for generating more specific ends and actions for a free agent.

Hegel's own advice is that the content of freedom can be worked out by means of his logical concept of the "concrete universal", a universal which is not dependent on its particulars for its content, but rather, somehow generates its content out of itself. ${ }^{38}$ The free will is an example of such a concrete, or self-particularizing, universal in that it need not appeal to its desires or inclinations to get particular content, but generates determinate ends on its own. Hegel makes no serious attempt in the Introduction to the Philosophy of Right to elaborate his doctrine of the concrete universal but instead simply cites his treatment of the 
issue in his logic. Rather than attempt to reconstruct that doctrine as a whole, I want instead simply to draw attention to one interesting, and relatively accessible, claim which Hegel makes about the idea of a concrete universal, which seems highly pertinent to his theory of freedom.

Hegel's interesting claim, from our point of view, is that the idea of a concrete, or selfparticularizing, universal can be understood in terms of a teleological, or ends-means, relationship This claim can be found, for instance, in a remark from the Science of Logic discussion of teleology: 'End", he asserts, "is the concrete universal, which possesses in its own self the moment of particularity and externality and is therefore active and the urge to repel itself from itself ${ }^{39}$ It is also implicit in Hegel's often repeated idea that the concept of a concrete universal finds application in the products of organic nature, in particular, and in anything guided by "inner purposiveness" more generally. ${ }^{40}$

Now, whatever else Hegel might mean by a concrete or self-particularizing universal, there is a relatively clear sense in which a purposively, or organically, understood entity can be thought of as generating its own particular content. An end, as Hegel argues in his discussion of teleology, points to certain specific means, which are the instrumental conditions of its realization. Likewise, an organism is an entity which adapts itself to ensure the realization of its goal of self-preservation. The "content" of an organism - its parts or "members" - consist in the means or instrumental conditions of its own survival. ${ }^{41}$ If a universal is viewed as in some way purposive or organic, then there is a straightforward sense in which it can be said to be self-particularizing and self-determining: it generates a particular content in the sense that it points to a determinate set of particulars that must be deployed if its purpose is to be achieved.

These various remarks on concrete universals, teleology and organicism, which have typically been ignored in discussions of Hegel's theory of freedom, suggest that a very simple and familiar idea about the content of self-determination may be at work in Hegel's thought. For all the fancy jargon of the Introduction to the Philosophy of Right, he seems, at least in part, to have in mind the simple idea that a will is self-determining when and because its actions contribute to the realization of its ends and purposes. In some sense, at least, the generation of the content of autonomy simply involves the application of Kant's famous dictum that 'he who wills the end, wills (so far as reason has decisive influence on his action) also the means which are indispensably necessary and in his power". ${ }^{2}$

Of course, on its own, this does not help much to provide content for the free will since ends-means rationality only generates particular content where there are given ends. However, if this conclusion is combined with the earlier point that any free agent as such is committed to the end of maintaining his own freedom, we arrive at the claim that the particular content of Hegelian freedom is given by the means of achieving, or instrumental conditions, of freedom. A free or autonomous agent does not take any of his given desires or inclinations, or any instruction from an external authority, as a sufficient reason-for-action but endeavours to determine his own activity by employing his own thought and reason alone. A decisive 
reason-for-action for such an agent, Hegel is claiming, is that the end or action in question contributes to the maintenance of his own freedom and independence. Freedom, on this view, has a recursive structure ${ }^{43}$ : the ends and determinations that give content to freedom turn out to be the ends that agents must pursue if they are to be in a position to deliberate about what ends and determinations give content to freedom.

Hegel explicitly confirms that freedom has this recursive structure in an important passage in the Lectures on the Philosophy of History:

When the spirit strives towards its centre, it strives to perfect its own freedom; and this striving is fundamental to its nature. To say that spirit exists would at first seem to imply that it is a completed entity. On the contrary, it is by nature active, and activity is its essence; it is its own product, and is therefore its own beginning and its own end. Its freedom does not consist in static being, but in a constant negation of all that threatens to destroy (aufheben) freedom. ${ }^{44}$

Here Hegel affirms that the content of freedom is given by the process of 'striving" for freedom. There is no "static being" of freedom; only the dynamic process of establishing freedom and maintaining freedom, the process of negating all that threatens to destroy freedom. Freedom, on this view, consists in the perpetual struggle for liberation.

3 Hegel's general strategy for defending the reciprocity thesis, then, will involve an attempt to show that by subjecting oneself to the ethical requirements of one's community one is somehow helping to establish and maintain one's own freedom; one is engaged in the "Constant negation of all that threatens to destroy freedom". Freedom consists in rational selfdetermination and this means engaging in actions that one can fully endorse on a rational basis. Freedom and ethics are reciprocally linked because in acting ethically an individual is contributing to the realization of an end which is partially constitutive of his status as a free agent - the preservation and promotion of his own freedom. As I indicated earlier, however, this claim about ethics is by no means self-evident, as it seems to involve a jump from a selfregarding consideration (establishing and maintaining one's own freedom and independence) to an other-regarding one (a concern for the freedom and welfare of other members of the community). Why should acting ethically be considered a contribution to the development and maintenance of one's own freedom? Interestingly Hegel does have an account to offer here, and, although there is insufficient space to allow for any detailed exploration of it, it is worthwhile just setting out some of its main steps in order to complete the argument. Once again there are three points worth making:

(a) The first is that Hegel assumes that the capacities, goals and attitudes of a free agent - his commitment, for instance, to engaging in the kind of reflection and deliberation that is required by the conception of freedom as rational self-determination - are not a natural property of all 
aduit human beings but are only acquired as a result of a process of education and socialization that he sometimes terms Bildung.

(b) Secondly, central to this Bildung process is the idea of recognition: Hegel holds that to become and remain a free agent one must enjoy the recognition of other agents. Moreover, famously, this is not a recognition that can be workably coerced out of others, but must be mutual. A necessary condition of developing and sustaining one's free agency, then, is that one be part of a community of mutually recognising free agents.

(c) Finally, Hegel argues that a community of mutually recognising free agents can itself only be established and maintained if agents are committed to the ethical requirements defined by its central institutions - the family, civil society and the state. This is in part because recognition must be mediated by certain specific social customs and practices but also because a community of mutual recognition is likely to be a fragile construction that can only be secured if its members are sufficiently motivated by a concern for one another.

In summary, then, Hegel's case for the reciprocity thesis might be set out as follows. An agent who abstracts from all given authority or desire still has one reason-for-action: he has reason to establish and maintain his own freedom and independence. The agent need not deliberate about, or seek a justification for, this end, because it is a condition of engaging in the kind of practical reasoning that is constitutive of free agency that he be committed to it. This foundational reason-for-action can then be developed into more specific reasons and ends by investigating what kinds of ends and arrangements are required if individuals are to become and remain free agents. The argument for the reciprocity thesis is completed with a defense of the claim that one crucial condition of becoming and remaining free is that agents must, in general, be committed to the ethical requirements of their community. By acting ethically, an agent is contributing to the development and maintenance of his own freedom and thus is free. $^{45}$

Alan Patten

University of Exeter

1 Henry E Allison Kant's Theory of Freedom (Cambridge: Cambridge University Press, 1990) Chapter 11.

2 One difference between the Kantian and Hegelian formulations of the thesis is that the former identifies freedom with the capacity to follow ethical requirements whereas the latter identifies it with actually exercising this capacity. On Kant's view that freedom is a capacity, see Allison, Kant's Theory of Freedom, pp 94-99; and Thomas E Hill, Jr, 'Kant's Argument For The Rationality of Moral Conduct", Pacific Philosophical Quarterly 66 (1985), pp 11-12. For a comparison of Kant and Hegel on this issue, see Allen W Wood, Hegel's Ethical Thought (Cambridge: Cambridge University Press, 1990) p 39. In what follows, nothing, so far as I can see, turns on this difference in formulation.

3 Immanuel Kant Groundwork of the Metaphysics of Morals, translated by $\mathrm{H} \mathbf{J}$ Paton as The Moral Law (London: Unwin Hyman, 1948), Royal Prussian Academy p 447. 
4 Immanuel Kant Critique of Practical Reason, translated by Lewis White Beck (New York: Macmillan, 1956), Royal Prussian Academy pp 29-30 and 42-50.

$5 \quad$ Eg at Groundwork, pp 400-02.

6 Elements of the Philosophy of Right (PR), translated by H B Nisbet, edited by Allen W Wood (Cambridge: Cambridge University Press, 1991), \$133A

$7 \quad$ PR $\S \S 148$ and 149 respectively.

8 For discussion, see Allison, Kant's Theory of Freedom, pp 94-99, and Hill, 'Kant's Argument For the Rationality of Moral Conduct".

9 See, for instance, Hegel: Werke Theorie Werkausgabe (Werke) (Frankfurt: Suhrkamp Verlag, 1970), Volume X, $\$ 475$.

10 See, for instance, PR $\$ 124$.

11 Eg Werke, Volume XII, pp 216, 386, 403, 524; Die Philosophie des Rechts: Die Mitschriften Wannenmann (Heidelberg 1817-1818) und Homeyer (Berlin 1818-1819), edited by K-H Ilting ((Stuttgart: Klett-Cotta Verlag, 1983), pp 38, 211; Vorlesungen über Rechisphilosophie, Volume IV, edited by K-H Ilting (Stuttgart: Fromman Verlag, 1974), p 80.

12 I defend at length this interpretation of Hegel's conception of freedom in my DPhil. Dissertation, Hegel's ldea of Freedom: An Interpretation and Defense, submitted to the University of Oxford in January 1996.

13 Eg at PR $\S 135$.

14 For sympathetic discussions of Hegel's objections, see W H Walsh Hegelian Ethics (London, Macmillan, 1969), Chapter 4; Charles Taylor, Hegel (Cambridge: Cambridge University Press, 1975), p 371; and Steven B Smith, Hegel's Critique of Liberalism (Chicago: University of Chicago Press, 1989), pp 73-75. For recent attempts to defend Kant against the charge that the moral law is empty, see Christine Korsgaard, 'Kant's Formula of Universal Law', Pacific Philosophical Quarterly, Volume 66 (1985); Onora O'Neill, Acting on Principle: An Essay on Kantian Ethics (New York: Columbia University Press, 1975), Chapter 5; Andreas Wildt, Autonomie und Anerkennung (Stuttgart: Klett-Cotta, 1982), pp 84-96; and Allen Wood, Hegel's Ethical Thought, pp 155-61. My discussion most closely follows Korsgaard.

15 This is how Korsgaard interprets Kant's test in 'Kant's Formula of Universal Law'. Even if Korsgaard's interpretation of how Kant understood the categorical imperative test is incorrect it remains the case that there is a non-vacuous Kantian understanding of the test. This is damaging to Hegel's critique, which is aimed at a whole approach to ethics (which he terms Moralität as opposed to Sittlichkeit) and not merely at Kant's own position.

16 Christine Korsgaard, 'Morality as Freedom", in Kant's Practical Philosophy Reconsidered, edited by Yirmiyuhu Yovel (Dordrecht: Kluwer Academic Publishers, 1989), p 28; cf. Allen Wood, Hegel's Ethical Thought, pp 161-67, Robert Pippin, "Idealism and Agency in Kant and Hegel", Journal of Philosophy (1991), p 539, and Taylor, Hegel, pp 373, 559-62.

17 Taylor, Hegel, p 373.

18 Vorlesungen über Rechtsphilosophie, Volume IV, p 118.

19 As Wood, Hegel's Ethical Thought, p 163, has suggested, Werke, Volume VIII, $\$ 54$ also seems to manifest an awareness of this contradiction; see also Werke, Volume $\mathrm{XX}$, pp 367-68.

20 Grounctwork, pp 446-47, and Critique of Practical Reason, pp 28-9, respectively.

21 Allison, Kant's Theory of Freedom, Chapter 11; and 'On a Presumed Gap in the Derivation of the Categorical Imperative", Philosophical Topics, Vol 19, No. 1 (1991), p 10. 
Critigue of Practical Reason, p 29.

Obviously, this is just one possible line of criticism that might be pursued here. A second would be to argue that (1) is incoherent because it wrongly supposes that there are what Bernard Williams has called "external reasons", that is, reasons that an agent might have independently of his given desires, inclinations, commitments, projects, and so on (what Williams calls his 'motivational set'). See Williams, 'Internal and External Reasons", in Moral Luck (Cambridge: Cambridge University Press, 1981). Nothing in the argument of this paper assumes either that there are or that there are not external reasons.

See Critique of Practical Reason, p 27, and Groundwork, p 402.

Here I follow Wood, Hegel's Ethical Thought, pp 161-67. See also Allison, Kant's Theory of Freedom, Chapter 11, and 'On a Presumed Gap", pp 3-5; Hill, 'Kant's Argument for the Rationality of Moral Conduct", p 19; and Rüdiger Bittner, What Reason Demands, translated by Theodore Talbot (Cambridge: Cambridge University Press, 1989), p 85n187.

Wood, Hegel's Ethical Thought, pp 164-65. Allison, "On a Presumed Gap", p 12. Allison, "On a Presumed Gap", p 12. Korsgaard, "Morality as Freedom", pp 29-31.

30 Korsgaard, "Morality as Freedom", p 30.

31 Hegel himself joins Korsgaard in attributing the idea to Kant: see Werke, Volume XII, pp 524-25, and Werke, Volume XX, pp 366-67. p 39, and PR \$21A, respectively.

33 See, for example, Die Vernunft in der Geschichte, edited by
Felix Meiner Verlag, 1955). pp 56, 183, and PR $\$ \$ 26 \mathrm{~A}, 57$

Die Vernunft in der Geschichte, p 56.

35 It seems to me that Charles Taylor is making a similar point in Hegel, p 93: 'Surely there must be some goal which is taken as the starting point, even if everything that is done is determined by strict reasoning from this basic aim. For otherwise how can reasoning by itself come to any conclusion as to what action to take? But then is this basic goal not simply given? The answer is, in a sense, yes. But not in a sense which need negate the radical freedom of Geist. For Geist can be thought to have as its basic aim simply that spirit, or rational subjectivity, be; and the rest can be thought to follow of necessity...But then the only input into this skein of rational necessity would be the goal, let rational subjectivity be. Once this 'decision' is taken, the rest flows of itself. But it cannot be thought of as a limitation on the freedom of Geist that this 'decision' is preformed. That subjectivity should be is not a limit on its freedom, but the very basis of it; and that it should be rational, ie, expressed in conceptual consciousness, is thought by Hegel to belong to the very essence of subjectivity".

36 There would be a number of problems with such a conception of rational selfdetermination: (1) the "external reasons" problem mentioned briefly in Section 3 above; (2) the problem that such a conception of freedom seems to blur the distinction between determination by reason and determination by self; and (3) the various problems attending the idea of a "noumenal" realm.

37 Vorlesungen über Rechtsphilosophie, Volume IV, p 79.

38 See, for instance, PR $\S \S 7$ and 24 , and Werke, Volume X, $\S 469 \mathrm{~A}$.

39 Science of Logic, translated by A V Miller (London: George Allen \& Unwin, 1969), p 739.

$40 \quad$ Werke, Volume VIII, $\S \S 55$ and 57. 
41 Werke, Volume VIII, $\S 57$.

42 Kenneth Westphal also suggests that Hegel's 'argument rests on an unspoken principle much like Kant's principle of rational willing: Whoever rationally wills an end is rationally committed to willing the necessary means or conditions for achieving that end". See Westphal, 'Context and structure of Philosophy of Right", in Cambridge Companion to Hegel, ed Frederick Beiser (Cambridge: Cambridge University Press, 1993), p 247.

43 I am indebted to Michael Rosen for suggesting this term to me.

44 Die Vermunft in der Geschichte, p 55.

45 I am grateful to Jessica Brown, Michael Rosen, and the participants in the Wolfson College Philosophy Society, and Nuffield College Political Theory Workshop, for comments on earlier drafts of this paper. 